\title{
Nurmen täydennyskylvön vaikutus satoon aukkoisessa kasvustossa
}

\author{
Maarit Hyrkäs ${ }^{1}$, Sanna Kykkänen ${ }^{1}$, Perttu Virkajärvi ${ }^{1}$, Johanna Kanninen², Jenni Laakso ${ }^{2}$ ja Panu \\ Korhonen ${ }^{1}$ \\ ${ }^{1}$ Luonnonvarakeskus (Luke), Tuotantojärjestelmät, Halolantie 31 A, 71750 Maaninka, \\ etunimi.sukunimi@luke.fi \\ ${ }^{2}$ Luonnonvarakeskus (Luke), Tutkimusinfrastruktuuripalvelut, Halolantie 31 A, 71750 Maaninka, \\ etunimi.sukunimi@luke.fi
}

Onnistuneella täydennyskylvöllä voidaan jatkaa nurmen ikää ja alentaa siten perustamiskustannuksia. Vaikutusten ja kannattavuuden kvantitatiivinen mittaaminen on kuitenkin haasteellista mm. lukuisten eri täydennyskylvötekniikoiden ja nurmien vaihtelevan tiheyden vuoksi. Aukkoisen nurmen täydennyskylvön onnistumista pidetään todennäköisempänä kuin tasaisesti harvan. Nurmet Rahaksi hankkeessa tutkittiin kahdella kokeella nurmen täydennyskylvön vaikutusta sadon määrään ja sulavuuteen aukkoisuudeltaan erilaisissa timotei-nurminatanurmissa.

Kokeet toteutettiin Luonnonvarakeskuksen Kuopion toimipaikassa Maaningalla vuosina 2015-2017. Koeasetelmana oli osaruutukoe viidellä toistolla. Pääruutuna oli nurmen aukkoisuus (täystiheä, 15\% aukkoja, 28\% aukkoja, 40\% aukkoja) ja osaruutuna täydennyskylvö/ei täydennyskylvöä. Aukot tehtiin kasvustoon erikokoisia pyöreitä reikiä (halkaisija 20, 30 ja $40 \mathrm{~cm}$ ) sisältävän muovisapluunan sekä glyfosaatin avulla. Täydennyskylvöt (tim-nn-seos, $12 \mathrm{~kg} \mathrm{ha}^{-1}$ ) tehtiin koeruutukylvökoneella käyttäen vantaita. Ensimmäisessä kokeessa (Koe 1) nurmi perustettiin suojaviljaan keväällä 2013, kasvusto aukotettiin syksyllä 2014 ja täydennyskylvö tehtiin keväisin 2015, 2016 ja 2017. Toisen kokeen (Koe 2) nurmi perustettiin suojaviljaan keväällä 2014, aukotettiin syksyllä 2015 ja täydennyskylvettiin vain kerran keväällä 2016. Sato korjattiin kaksi kertaa vuonna 2015 ja kolme kertaa vuosina 2016 ja 2017. Kokeilta määritettiin ruuduittain sadon kuivapaino sekä rehuarvot. Lisäksi havainnoitiin täydennyskylvön orastumista silmämääräisesti.

Keväällä 2015 täydennyskylvö ei onnistunut kunnolla. Ensimmäisessä sadossa täydennyskylvö alensi satoa $260 \mathrm{~kg} \mathrm{ka} \mathrm{ha-1}$, mikä johtui todennäköisesti vantaiden aiheuttamista vaurioista. Toisessa sadossa satoeroa ei ollut. Keväällä 2016 täydennyskylvö tehtiin molemmille kokeille ja se onnistui hyvin etenkin kokeella 2. Kokeessa 1 täydennyskylvö laski ensimmäistä satoa $130 \mathrm{~kg} \mathrm{ka} \mathrm{ha}^{-1}$, mutta nosti toista satoa $120 \mathrm{~kg} \mathrm{ka} \mathrm{ha-1}$. Kokeessa 2 täydennyskylvö nosti toista satoa $110 \mathrm{~kg} \mathrm{ka} \mathrm{ha}^{-1}$. Keväällä 2016 tehdyn täydennyskylvön vaikutus oli kokeella 2 silmämääräisesti havaittavissa nurmen tiheydessä. Vuonna 2017 täydennyskylvö nosti ensimmäistä satoa kokeella 2 keskimäärin 340 kg ka ha-1 ja $760 \mathrm{~kg} \mathrm{ka} \mathrm{ha}^{-1}$, kun aukkoja oli $40 \%$. Toisessa sadossa sadon määrä nousi $280 \mathrm{~kg} \mathrm{ka} \mathrm{ha}^{-1}$, kun aukkoja oli $40 \%$, mutta laski $210 \mathrm{~kg} \mathrm{ka} \mathrm{ha}^{-1}$ aukottomalla koejäsenellä. Kokeella 1 vaikutus näkyi lähes merkitsevästi vain toisessa sadossa.

Aukkoisuus laski selvästi sadon määrää aukottamista seuraavassa sadossa, mutta vaikutus oli odotettua pienempi myöhemmissä sadoissa. Nurmi kompensoi aukkoisuutta aukkojen laitojen korkeammalla ja rotevammalla kasvustolla. Ilmiötä ei voine yleistää suurempiin aukkoihin. Aukot täyttyivät rikkakasveilla ja aiheuttivat kasvinsuojeluruiskutuksen tarpeen. Täydennyskylvön yksi etu onkin rikkakasvipaineen vähentäminen.

Kokeissa havaittu täydennyskylvön vaikutus sadon määrään sekä sulavuuteen oli vähäinen myös silloin, kun nurmi oli hyvin aukkoinen ja täydennyskylvö onnistui.

Asiasanat: sato, nurmiheinät, täydennyskylvö 


\section{Johdanto}

Pohjoisten nurmilajien satopotentiaali laskee luontaisesti keskimäärin kolmannen satovuoden jälkeen (Virkajärvi ym. 2015) ja tämän seurauksena nurmien uudistamisväli on Suomessa keskimäärin 3-5 vuotta. Uudistamistarve syntyy, kun nurmet harvenevat ja aukkoontuvat muun muassa talvituhojen ja lakoontumisen seurauksena. Tiheä uudistamisväli lisää perustamiskustannuksia nurmivuotta kohden, joten onnistuneella kasvuston ikää pidentävällä täydennyskylvöllä voidaan alentaa nurmien uudistamisesta syntyviä kustannuksia. Täydennyskylvön onnistuminen ja kannattavuus on kuitenkin usean osatekijän summa ja toistaiseksi tutkimustieto heinänurmien täydennyskylvöstä on ollut monilta osin puutteellista. Täydennyskylvön onnistumiseen vaikuttavia tekijöitä on ajateltu olevan mm. riittävä kevätkosteus, siemenen saaminen maakosketukseen sekä riittävän aikainen kylvö, jotta siemenet ehtivät orastua ja lähteä kasvuun ennen kuin nurmikasvusto alkaa liiaksi varjostaa taimia (Kurki 2010). Nurmet Rahaksi -hankkeessa tutkittiin kahdella kokeella nurmen täydennyskylvön vaikutusta sadon määrään ja sulavuuteen aukkoisuudeltaan erilaisissa timotei-nurminatanurmissa.

\section{Materiaali ja menetelmät}

Kaksi erillistä kenttäkoetta toteutettiin Luonnonvarakeskuksen Maaningan (Kuopio) toimipisteessä Pohjois-Savossa vuosina 2015-2017. Kokeet toteutettiin vuonna 2013 (Koe 1) ja 2014 (Koe 2) perustetuilla nurmiruuduilla $\left(12 \mathrm{~m}^{2}\right)$ osaruutukokeina viidellä toistolla. Molemmat kokeet sijaitsivat peltolohkoilla, jonka maalaji oli karkea hieta, fosfori luokassa tyydyttävä ja maassa runsaasti reservikaliumia. Koeruuduille perustettiin timotei-nurminata (70:30, $\left.25 \mathrm{~kg} \mathrm{ha}^{-1}\right)$-kasvusto suojaviljaan (Wolmari-ohra), joka korjattiin kokoviljana. Kokeessa 1 seos oli Tuure-Inkeri ja kokeessa 2 TenhoInkeri. Pääruutuna toimi aukkoisuus. Aukot tehtiin kasvustoon erikokoisia pyöreitä reikiä (halkaisijat 20, 30 ja $40 \mathrm{~cm}$ ) sisältävien muovisapluunoiden avulla. Kasvusto käsiteltiin reikien kohdalta glyfosaatilla käyttäen joko kannettavaa ruiskua tai sivelysauvaa. Aukkoisuustasoja oli neljä: ei aukkoja, 15\% aukkoja, 28\% aukkoja ja 40\% aukkoja, jotka määräytyivät reikien osuutena koko ruudun pintaalasta. Glyfosaatti tuhosi kasvustosta tavoiteltua suuremman osan, mutta muutos kasvuston tiheydessä oli kuitenkin tasainen. Siten tästä ei ollut haittaa kokeen toteuttamisen kannalta, mutta tuloksia kannattaa arvioida mieluummin suhteessa kevättiheysmäärityksiin kuin glyfosaatilla käsiteltyjen aukkojen pintaaloihin käsittelyhetkellä. Osaruutuna kokeissa toimi täydennyskylvö/ei täydennyskylvöä. Kokeen 1 aukotus tehtiin 25.-26.9.2014 ja täydennyskylvö tehtiin keväisin vuosittain (2015, 2016 ja 2017, Taulukko 1). Koe 2 aukotettiin syksyllä 2015 (29.9. ja 5.10.) ja täydennyskylvö tehtiin vain kertaalleen keväällä 2016 (Taulukko 1). Täydennyskylvöt $\left(12 \mathrm{~kg} \mathrm{ha}^{-1}\right)$ tehtiin samoilla lajikkeilla, samalla seossuhteella ja samalla ruutukylvökoneella kuin alkuperäisessä kylvössä. Kylvökone oli ruutumittakaavan kone (Wintersteiger AG, Itävalta; työleveys 1,5 m), jonka vantaiden avulla siemenet saatiin makkosketukseen.

Sato korjattiin vuonna 2015 kaksi kertaa ja 2016-2017 kolme kertaa (Taulukko 1). Koe 1 sai vuonna 2015 hehtaaria kohden mineraalilannoitteina $190 \mathrm{~kg} \mathrm{~N}$ (1. sadolle $100 \mathrm{~kg}$, 2. sadolle $90 \mathrm{~kg}$ ), $15 \mathrm{~kg}$ P ja 50 kg K ja vuosina 2016 ja 2017 hehtaaria kohden 240 kg N (100+100+40), 15 kg P ja 46 kg K. Koe 2 sai vuosina 2016 ja 2017 mineraalilannoitteina hehtaaria kohden $240 \mathrm{~kg} \mathrm{~N}(100+100+40), 10 \mathrm{~kg} P$ ja 90 kg K. Rikkakasvit torjuttiin kokeilta tarvittaessa (rikkojen osuus kasvustossa >5\%). Vuonna 2015 kasvinsuojeluruiskutus tehtiin kymmenen päivää täydennyskylvön jälkeen. Vuonna 2016 vasta itäneitä versoja haluttiin suojella mahdollisilta ruiskutusvaurioilta. Kasvinsuojeluruiskutus toteutettiin kesäkuun lopussa, kun nurminadan taimissa oli 2-3 kasvulehteä. Tästä johtuen kokeella 2 aukkoisuustasojen 28\% ja 40\% koeruutujen aukoissa kasvoi merkittävä määrä rikkakasveja etenkin toisessa sadossa. Korjuun yhteydessä määritettiin kasvuston rikkakasvien osuus kahdelta suurimmalta aukkoisuustasolta ruuduittain (rikkojen osuus kasvustossa $>5 \%$ ) noin 450-750 g kokoisista näytteistä, rikkakasvit poistettiin analyysinäytteistä ja niiden osuus kuiva-ainesadosta. Koejäseniltä määritettiin kuiva-ainesato (Kasato, kg ka ha-1) kaikista niitoista sekä otettiin ruuduittain näytteet, joista analysoitiin D-arvo (g kg1 ka) NIR-menetelmällä (Valio Oy, Seinäjoki). Energiasato (ME-sato, GJ ha ${ }^{-1}$ ) laskettiin kaavalla D-arvo $\times 0,016 \times$ Kasato $\times 1000^{-1}$. Kaikilta ruuduilta määritettiin lisäksi silmämääräisesti kevättiheydet ja syystiheydet. Täydennyskylvön orastumista havainnoitiin kolmelta aukotetulta koejäseneltä vuosina 2015 ja 2016. Vuonna 2015 havainnoitiin silmämääräisesti itäneiden versojen osuutta halkaisijoiltaan erikokoisissa aukoissa. Vuonna 2016 koeruutujen erikokoisista 
aukoista havainnoitiin täydennyskylvörivejä $5 \mathrm{~cm}$ :n pituisilta osilta, ja mitattiin kuinka suurelta osuudelta niistä löytyy itäneitä versoja, sekä montako versoa $5 \mathrm{~cm}: n$ riviosalla keskimäärin oli. Tilastoanalyysit tehtiin SAS 9.4. ohjelmiston Mixed-proseduurilla käyttäen osaruutukokeen mallia, jossa aukkoisuus, täydennyskylvö ja näiden yhdysvaikutus olivat kiinteitä tekijöitä ja kerranne sekä kerranne×aukkoisuus -yhdysvaikutus satunnaisia tekijöitä. Mallissa käytettiin Kenward-Rogerin vapausasteiden korjausmenetelmää ja parivertailut tehtiin Tukeyn testillä.

Taulukko 1. Kokeilla tehtyjen viljelytoimenpiteiden ajankohdat

\begin{tabular}{lcccccc}
\hline & \multicolumn{3}{c}{ Koe 1} & & & \multicolumn{2}{c}{ Koe 2} \\
\cline { 2 - 4 } \cline { 6 - 7 } & 2015 & 2016 & 2017 & & 2016 & 2017 \\
\hline Täydennyskylvö & 12.5. & 3.5. & 9.5. & & 3.5. & - \\
Kevättiheyshavainnot & 12.5. & & & & 19.5. & \\
Rikkakasvitorjunta & 22.5. & $30.6 . / 17.8$ & - & & $30.6 . / 17.8$. & - \\
Lannoitus 1. sadolle & 14.5. & 10.5. & 12.5. & & 11.5. & 12.5. \\
Orastumishavainnot & 10.6. & 25.5. & - & & 25.5. & - \\
1. niitto & 12.6. & 10.6. & 27.6. & & 10.6. & 21.6. \\
Lannoitus 2.sadolle & 12.6. & 10.6. & 27.6. & & 10.6. & 21.6. \\
2. niitto & 30.7. & 21.7. & 3.8. & & 14.7. & 1.8. \\
Lannoitus 3.sadolle & - & 21.7. & 3.8. & & 15.7. & 1.8. \\
3. niitto & - & 6.9. & 18.9. & & 30.8. & 6.9. \\
\hline
\end{tabular}

\section{Tulokset}

Täydennyskylvöt tehtiin keväisin toukokuun alkupuolella. Taulukossa 2 kuvataan kevään kosteusolosuhteita. Keväällä 2015 lumi suli aikaisin, mutta etenkin toukokuun kahdella ensimmäisellä viikolla satoi paljon. Täydennyskylvö tehtiin melko myöhään, mutta sateista johtuen kosteutta oli maassa edelleen ja siemenet itivät. Vuonna 2016 täydennyskylvöt tehtiin aikaisemmin, ja ne onnistuivat paremmin kuin vuonna 2015. Vuonna 2017 lumi suli myöhään, ja pellon kuivumista jouduttiin odottelemaan hieman pidempään kuin 2016. Myös kasvukausi alkoi selvästi myöhemmin vuonna 2017 kuin kahtena edellisenä vuonna.

Taulukko 2. Lumen sulamispäivä sekä kevään sademäärät ja kasvukauden alkamispäivä Maaningalla koevuosina 2015-2017

\begin{tabular}{lcccc}
\hline & & 2015 & 2016 & 2017 \\
\hline Lumen sulamispäivä & & 10.4. & 9.4. & 4.5. \\
Sademäärä 1.-30.4. & $\mathrm{mm}$ & 33 & 42 & 35 \\
Sademäärä 1.-15.5. & $\mathrm{mm}$ & 44 & 4 & 3 \\
Sademäärä 16.-31.5. & $\mathrm{mm}$ & 15 & 11 & 24 \\
Kasvukauden alku & & 5.5. & 26.4. & 16.5. \\
\hline
\end{tabular}

Täydennyskylvöjen orastumishavaintoja ei analysoitu tilastollisesti. Vuonna 2015 keskimäärin 72\% täydennyskylvöistä näytti itäneen havainnointihetkellä 10.6. Vuonna 2016 kokeella 1 64\% havainnoiduista $5 \mathrm{~cm}$ kylvörivipätkistä sisälsi vähintään yhden itäneen verson, mutta yleisimmin versoja ei ollut yhtä enempää. Kokeella 2 täydennyskylvö onnistui paremmin, sillä $88 \% 5 \mathrm{~cm}$ pituisesta kylvörivin osasta sisälsi vähintään yhden verson. Yleisimmin uusia versoja oli $5 \mathrm{~cm}$ matkalla 1-2, mutta toisinaan 3-5. Vuonna 2017 silmämääräisiä orastumishavaintoja ei tehty.

\section{Aukkoisuus}

Kokeen 1 aukotuksen onnistuminen näkyi keväällä 2015 tehdyissä kevättiheyshavainnoissa (Taulukko 3). Tavoiteltujen 'ei aukkoja', '15\% aukkoja', '28\% aukkoja' ja ' $40 \%$ aukkoja' -koejäsenten sijaan kevättiheyksien perusteella lähtötilanteet olivat 5\% aukkoja, 40\% aukkoja, 63\% aukkoja ja 84\% aukkoja. Kahdella korkeimmalla aukkoisuustasolla täydennyskylvö-koejäsenten tiheydet ovat hieman matalammat (2 ja 5 \%-yksikköä) ei täydennyskylvöä -koejäseniin verrattuna, mikä voi teoriassa 
Taulukko 3. Täydennyskylvön vaikutus satoon (kg ka ha-1) niitoittain eri aukkoisuustasoilla kokeessa 1, jossa täydennyskylvö toistettiin vuosittain. Kun täydennyskylvön vaikutus on tilastollisesti merkitsevä, esitetään myös muutoksen suuruus kuiva-ainekiloina kullakin aukkoisuustasolla.

\begin{tabular}{|c|c|c|c|c|c|c|c|c|c|c|c|c|c|c|c|c|}
\hline \multirow[t]{2}{*}{ Aukk. } & \multirow[t]{2}{*}{ Täyd.kylvö } & \multicolumn{5}{|c|}{2015} & \multicolumn{6}{|c|}{2016} & \multicolumn{4}{|c|}{2017} \\
\hline & & Ktih $^{1}$ & 1. sato & muutos & 2. sato & Kok. sato & 1. sato & muutos & 2. sato & muutos & 3. sato & Kok. sato & 1. sato & 2. sato & 3. sato & Kok. sato \\
\hline ei aukkoja & ei & 95 & 4010 & & 4580 & 8590 & 4710 & & 3370 & & 2580 & 10660 & 3890 & 2620 & 1700 & 8220 \\
\hline ei aukkoja & kyllä & 95 & 3800 & -210 & 4450 & 8250 & 4500 & -210 & 3490 & +120 & 2680 & 10680 & 3980 & 2730 & 1780 & 8470 \\
\hline 15\% auk. & ei & 60 & 3200 & & 4460 & 7650 & 4700 & & 3280 & & 2560 & 10530 & 4020 & 2580 & 1660 & 8250 \\
\hline 15\% auk. & kyllä & 60 & 2950 & -250 & 4730 & 7680 & 4510 & -190 & 3370 & +90 & 2540 & 10420 & 3800 & 2650 & 1690 & 8140 \\
\hline 28\% auk. & ei & 38 & 2440 & & 4750 & 7190 & 4470 & & 3300 & & 2570 & 10340 & 3900 & 2670 & 1710 & 8280 \\
\hline 28\% auk. & kyllä & 36 & 2020 & -420 & 5000 & 7180 & 4480 & +10 & 3480 & +180 & 2610 & 10570 & 3930 & 2650 & 1720 & 8300 \\
\hline $40 \%$ auk. & ei & 19 & 1450 & & 4860 & 6310 & 4620 & & 3190 & & 2520 & 10330 & 3860 & 2480 & 1750 & 8090 \\
\hline $40 \%$ auk. & kyllä & 14 & 1300 & -150 & 4740 & 6040 & 4460 & -160 & 3280 & +90 & 2480 & 10230 & 3990 & 2640 & 1700 & 8330 \\
\hline \multirow{4}{*}{ Merk. } & $\mathrm{SEM}^{2}$ & 1.1 & 157 & & 138 & 199 & 117 & & 58 & & 86 & 186 & 167 & 105 & 70 & 224 \\
\hline & Aukk. & $* * *$ & $* * *$ & & $*$ & $* * *$ & & & $*$ & & & & & & & \\
\hline & Täyd.kylvö & $* * *$ & $* * *$ & & & & * & & $* *$ & & & & & 0 & & \\
\hline & Yhdysv. & $* * *$ & & & & & & & & & & & 0 & & & \\
\hline
\end{tabular}

${ }^{1}$ Ktih = kevättiheys-\%; ${ }^{2}$ SEM = keskiarvon keskivirhe; Tilastolliset merkitsevyydet: *** $\mathrm{P}<0.001,{ }^{* *} \mathrm{P}<0.01, * \mathrm{P}<0.05,0 \mathrm{P}<0.10$

Taulukko 4. Täydennyskylvön vaikutus satoon ( $k g$ ka ha $\left.{ }^{-1}\right)$ niitoittain eri aukkoisuustasoilla kokeessa 2, jossa täydennyskylvö tehtiin vain ensimmäisenä satovuotena. Kun täydennyskylvön vaikutus on tilastollisesti merkitsevä, esitetään myös muutoksen suuruus kuiva-ainekiloina kullakin aukkoisuustasolla.

\begin{tabular}{|c|c|c|c|c|c|c|c|c|c|c|c|c|c|}
\hline \multirow[t]{2}{*}{ Aukkoisuus } & \multirow[t]{2}{*}{ Täyd.kylvö } & \multicolumn{6}{|c|}{2016} & \multicolumn{6}{|c|}{2017} \\
\hline & & Ktih $^{1}$ & 1. sato & 2. sato & muutos & 3. sato & Kok. sato & 1. sato & muutos & 2. sato & 3. sato & Kok. sato & muutos \\
\hline ei aukkoja & ei & 99 & 4890 & 3220 & & 3120 & 11030 & 4090 & & 3550 & 1930 & 9570 & \\
\hline ei aukkoja & kyllä & 100 & 4710 & 3290 & +70 & 3050 & 11060 & 4200 & +110 & 3340 & 1850 & 9400 & -170 \\
\hline 15\% aukkoja & ei & 76 & 3680 & 3190 & & 2880 & 9750 & 3910 & & 3480 & 1920 & 9310 & \\
\hline 15\% aukkoja & kyllä & 76 & 3620 & 3320 & +130 & 2760 & 9710 & 4080 & +170 & 3520 & 1840 & 9430 & +120 \\
\hline 28\% aukkoja & ei & 60 & 3090 & 3230 & & 2590 & 8910 & 3700 & & 3420 & 1790 & 8920 & \\
\hline 28\% aukkoja & kyllä & 58 & 3030 & 3420 & +190 & 2610 & 9060 & 4010 & +310 & 3510 & 1790 & 9310 & +390 \\
\hline 40\% aukkoja & ei & 28 & 2050 & 3060 & & 2360 & 7810 & 3630 & & 3350 & 1700 & 8670 & \\
\hline $40 \%$ aukkoja & kyllä & 31 & 2020 & 3110 & +50 & 2530 & 7670 & 4390 & +760 & 3630 & 1740 & 9780 & +1110 \\
\hline \multirow{4}{*}{ Merkitsevyys } & SEM $^{2}$ & 3.3 & 164 & 99 & & 102 & 279 & 95 & & 78 & 39 & 134 & \\
\hline & Aukkoisuus & $* * *$ & $* * *$ & & & $* * *$ & $* * *$ & $*$ & & & $* * *$ & $*$ & \\
\hline & Täyd.kylvö & & & $*$ & & & & $* * *$ & & & & $* * *$ & \\
\hline & Yhdysv. & & & & & & & $* *$ & & $*$ & & $* * *$ & \\
\hline
\end{tabular}

${ }^{1}$ Ktih = kevättiheys-\%; ${ }^{2}$ SEM $=$ keskiarvon keskivirhe; Tilastolliset merkitsevyydet: $* * * \mathrm{P}<0.001,{ }^{* *} \mathrm{P}<0.01, * \mathrm{P}<0.05,0 \mathrm{P}<0.10$ 
hieman vaikuttaa tuloksiin. Aukkoisuus laski odotetusti ensimmäisen sadon määrää (ei aukkoja vs. 40\% aukkoja -2530 kg ka ha-1), mutta sadot olivat korkeampia kuin kevättiheyksien perusteella olisi voinut olettaa. '15\% aukkoja' -koejäsenen sato oli 79\% täystiheän koejäsenen sadosta, '28\% aukkoja' koejäsenen 57\% ja '40 \% aukkoja' -koejäsenen 35\% täystiheästä, kun vastaavat kevättiheydet olivat $60 \%$, 37\% ja 17\%. Yllättäen toisessa sadossa korkein sato ja saatiin kaikkein aukkoisimmalla koejäsenellä (+280 kg ka ha ${ }^{-1}$ aukottomaan koejäseneen verrattuna). Ensimmäisessä sadossa aukkoisuus nosti D-arvoa (ei aukkoja vs. 40\% aukkoja $+22 \mathrm{~g} \mathrm{~kg}^{-1} \mathrm{ka}$ ), mutta laski sitä toisessa sadossa (-16 g kg-1 ka). Nurmi kompensoi aukkoisuutta toisessa sadossa aukkojen laitojen korkeammalla ja rotevammalla kasvustolla.

Vuonna 2016 aukkoisuudella ei ollut vaikutusta ensimmäisen sadon määrään eikä sulavuuteen kokeella 1. Toisessa sadossa aukkoisuus laski satoa $200 \mathrm{~kg} \mathrm{ka} \mathrm{ha}^{-1}$ (ei aukkoja vs. $40 \%$ aukkoja), mutta ei vaikuttanut D-arvoon. Kolmannessa sadossa ja kokonaissadossa aukkoisuudella ei ollut vaikutusta kasatoon. Kokeen 2 aukotuksen jäljiltä lähtötilanne ensimmäisen koevuoden keväällä 2016 oli ei aukkoja, 24\% aukkoja, 41\% aukkoja ja 70\% aukkoja. Osaruutujen (täydennyskylvö/ei täydennyskylvöä) välillä ei ollut eroja aukkoisuudessa. Ensimmäisessä sadossa aukotus laski satoa, kuten kokeessa 1. Aukkoisuustason '15\% aukkoja' (toteutunut kevättiheys 76\%) sato oli sekin 76\% täystiheän koejäsenen sadosta. Kahdella korkeimmalla aukkotasolla sadon määrä oli korkeampi kuin kevättiheys (64\% ja 42\% täystiheästä, kun vastaavat kevättiheydet olivat 59\% ja 30\%). Sadon määrän laskiessa sen D-arvo nousi (ei aukkoja vs. 40\%-aukkoja $689 \rightarrow 721 \mathrm{~g} \mathrm{~kg}^{-1} \mathrm{ka}$ ). ME-sadossa ilmiö oli vastaava kuin kuivaainesadossa. Tälläkään kokeella aukotuksella ei enää ollut tilastollisesti merkitsevää vaikutusta toisen sadon kuiva-ainesadon määrään, mutta aukkoisuus nosti sulavuutta tilastollisesti merkitsevästi (ei aukkoja vs. $40 \%$ aukkoja $696 \rightarrow 711 \mathrm{~g} \mathrm{~kg}^{-1} \mathrm{ka}$ ). Aukkoisuus laski satoa myös kolmannessa sadossa, mutta suhteessa vähemmän ('40\% aukkoja' koejäsenen sato oli $79 \%$ täystiheästä sadosta). Kokonaissadossa aukkoisuus laski satoa merkitsevästi (ei aukkoja vs. 40\% aukkoja $11040 \rightarrow 7740$ kg ka ha-1).

Vuonna 2017 kokeella 1 aukkoisuudella ei ollut enää havaittavissa mitään vaikutusta satoon. Myös kokeella 2 aukkoisuuden vaikutus satotasoon oli selvästi vähäisempi kuin edellisenä vuonna. Ensimmäisessä sadossa '28\% aukkoja' -koejäsenen sato oli $290 \mathrm{~kg} \mathrm{ka} \mathrm{ha}^{-1}$ matalampi kuin täystiheän koejäsenen, eikä muuta eroa ollut. Toisessa sadossa aukkoisuudella ei ollut merkitsevää vaikutusta, ja kolmannessa ' $40 \%$ aukkoja' -koejäsenen sato oli keskimäärin $170 \mathrm{~kg} \mathrm{ka} \mathrm{ha}^{-1}$ matalampi kuin täystiheän ja '15\% aukkoja' -koejäsenen. Aukkoisuus nosti kolmannen sadon sulavuutta (ei aukkoja vs. 40\% aukkoja $745 \rightarrow 753 \mathrm{~g} \mathrm{~kg}^{-1} \mathrm{ka}$ ). Kokonaissatoon aukkoisuudella ei ollut vaikutusta.

\section{Täydennyskylvö}

Vaikka orastumishavainnot kokeella 1 näyttivät positiivisilta kesän 2015 alussa, täydennyskylvöllä oli odotettua vähemmän vaikutusta koevuosien satotasoon. Vuoden 2015 ensimmäinen sato niitettiin tarkoituksella aikaisin, jotta täydennyskylvetyt versot saisivat valoa. Täydennyskylvön ei vielä ensimmäisessä sadossa odotettu vaikuttavan satoa nostavasti. Täydennyskylvö alensikin vuoden 2015 ensimmäistä satoa keskimäärin $260 \mathrm{~kg} \mathrm{ka} \mathrm{ha}^{-1}$ (2,9 GJ ha-1), mikä johtui todennäköisesti vantaiden aiheuttamista vaurioista (Taulukko 3). Toisessa sadossa ja koko kesän kokonaissadossa täydennyskylvöllä ei ollut vaikutusta sadon määrään, mutta se nosti hieman toisen sadon D-arvoa (680 $\rightarrow 683 \mathrm{~g} \mathrm{~kg}^{-1} \mathrm{ka}$ ). Ensimmäisen sadon D-arvo oli keskimäärin $742 \mathrm{~g} \mathrm{~kg}^{-1} \mathrm{ka}$.

Vuonna 2016 aloitettiin Koe 2 ja molemmille kokeille tehtiin täydennyskylvö. Kokeessa 1 täydennyskylvö laski vuoden 2015 tapaan ensimmäistä satoa $130 \mathrm{~kg} \mathrm{ka} \mathrm{ha}^{-1}\left(1,5 \mathrm{GJ}^{-1} \mathrm{ha}^{-1}\right)$, mutta nosti toista satoa $120 \mathrm{~kg} \mathrm{ka} \mathrm{ha}^{-1}\left(1,3 \mathrm{GJ} \mathrm{ha}^{-1}\right)$. Kolmannessa sadossa ja kesän kokonaissadossa täydennyskylvöllä ei ollut merkitsevää vaikutusta satoon. Täydennyskylvöllä ei ollut vaikutusta Darvoon, joka oli ensimmäisessä sadossa keskimäärin $695 \mathrm{~g} \mathrm{~kg}^{-1} \mathrm{ka}$, toisessa $686 \mathrm{~g} \mathrm{~kg}^{-1} \mathrm{ka}$ ja kolmannessa $712 \mathrm{~g} \mathrm{~kg}^{-1} \mathrm{ka}$. Syystiheysmääritysten perusteella täydennyskylvö oli nostanut tiheyttä '40\% aukkoja' koejäsenellä 15 prosenttiyksikköä $(60 \% \rightarrow 73 \%)$.

Kokeessa 2 kahdella korkeammalla aukkoisuustasolla esiintyi rikkakasveja, koska kasvinsuojeluruiskutusta ei tehty keväällä. Koejäsenellä ’28\% aukkoja' rikkakasveja oli keskimäärin $5 \%$ toisessa sadossa ja $2 \%$ kolmannessa sadossa, ja koejäsenellä ' $40 \%$ aukkoja' $12 \%$ toisessa sadossa ja 3\% kolmannessa sadossa. Sato- ja sulavuustulokset esitetään ilman rikkakasveja. Täydennyskylvö ei laskenut ensimmäisen sadon määrää tilastollisesti merkitsevästi, vaikka sadot olivatkin numeroarvoisesti pienempiä jokaisella aukkoisuustasolla. Toisessa sadossa täydennyskylvö nosti satoa 
keskimäärin $110 \mathrm{~kg} \mathrm{ka} \mathrm{ha}^{-1}$, mutta ME-satona ero ei ollut aivan tilastollisesti merkitsevä. Kolmannessa sadossa ja kesän kokonaissadossa täydennyskylvöllä ei ollut merkitsevää vaikutusta sadon määrään. Täydennyskylvöllä ei ollut vaikutusta D-arvoon, joka oli ensimmäisessä sadossa keskimäärin 703 g kg-

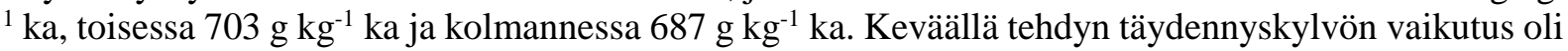
kokeella 2 loppukesästä silmin nähtävä, mutta syystiheysmääritysten perusteella täydennyskylvö oli nostanut nurmen tiheyttä tilastollisesti merkitsevästi vain '40\% aukkoja' -koejäsenellä (17 prosenttiyksikköä, $52 \% \rightarrow 69 \%$ ).

Vuonna 2017 kokeella 1 täydennyskylvö vaikutti satoon vain suuntaa antavasti toisessa sadossa, jolloin sadon määrä lisääntyi $80 \mathrm{~kg} \mathrm{ka} \mathrm{ha}^{-1}$. D-arvo oli ensimmäisessä sadossa $697 \mathrm{~g} \mathrm{~kg}^{-1} \mathrm{ka}$, toisessa $715 \mathrm{~g} \mathrm{~kg}^{-}$ ${ }^{1}$ ka ja kolmannessa $697 \mathrm{~g} \mathrm{~kg}^{-1} \mathrm{ka}$. Täydennyskylvö oli syystiheyksien perusteella nostanut ${ }^{4} 40 \%$ aukkoja' -koejäsenen tiheyttä 15 prosenttiyksikköä (64\% $\rightarrow 79 \%)$. Toisin kuin kokeella 1, kokeella 2 saatiin ensimmäistä kertaa käytännön kannalta merkittäviä sadonlisiä. Täydennyskylvö nosti ensimmäistä satoa kokeella 2 keskimäärin $340 \mathrm{~kg} \mathrm{ka} \mathrm{ha}^{-1}\left(3,6 \mathrm{GJ} \mathrm{ha}^{-1}\right)$ ja '40\% aukkoja' -koejäsenellä $760 \mathrm{~kg} \mathrm{ka} \mathrm{ha}^{-1}\left(8,1 \mathrm{GJ} \mathrm{ha}^{-1}\right)$. Toisessa sadossa sadon määrä nousi $280 \mathrm{~kg} \mathrm{ka} \mathrm{ha}^{-1}$, kun aukkoja oli 40\%, mutta laski $210 \mathrm{~kg} \mathrm{ka} \mathrm{ha}^{-1}$ aukottomalla koejäsenellä. Kolmannessa sadossa täydennyskylvöllä ei ollut merkitsevää vaikutusta. Kokonaissadossa täydennyskylvö nosti satoa keskimäärin $360 \mathrm{~kg} \mathrm{ka} \mathrm{ha}^{-1}(3,7$ GJ ha $\left.{ }^{-1}\right)$ ja ' $40 \%$ aukkoja' -koejäsenellä $1100 \mathrm{~kg} \mathrm{ka} \mathrm{ha}^{-1}\left(11,4 \mathrm{GJ}^{-1} \mathrm{~h}^{-1}\right)$. D-arvo oli ensimmäisessä sadossa $702 \mathrm{~g} \mathrm{~kg}^{-1} \mathrm{ka}$, toisessa $695 \mathrm{~g} \mathrm{~kg}^{-1} \mathrm{ka}$ ja kolmannessa $749 \mathrm{~g} \mathrm{~kg}^{-1} \mathrm{ka}$, eikä täydennyskylvöllä ollut vaikutusta. Syystiheysmääritysten perusteella täydennyskylvö oli nostanut nurmen tiheyttä ' $15 \%$ aukkoja' -koejäsenellä 18 prosenttiyksikköä $(77 \% \rightarrow 95 \%)$, '28\% aukkoja' -koejäsenellä 23 prosenttiyksikköä $(66 \% \rightarrow 89 \%)$ ja '40\% aukkoja' -koejäsenellä 35 prosenttiyksikköä (54\% $\rightarrow$ 89\%).

\section{Tulosten tarkastelu}

Nurmen aukkoisuuden vaikutukset satotasoon eivät olleet tämän tutkimuksen varsinainen tutkimuskohde, vaan mielenkiinto kohdistui täydennyskylvön ja aukkoisuustason yhdysvaikutukseen. Nurmen vahva aukkojen kompensointikyky korkeammalla ja rotevammalla kasvustolla oli kuitenkin mielenkiintoinen ja yllättävä havainto, joka johtunee muutoksista valon tunkeutumisessa aukkoiseen kasvustoon. Osin kyse voi olla myös runsaammasta käytettävissä olevien ravinteiden määrästä suhteessa ravinteita käyttävien versojen määrään. Tämän kokeen perusteella näytti siltä, etteivät pienet aukot nurmessa välttämättä vaikuta negatiivisesti satotasoon. Peltomittakaavassa aukot ovat usein suurempia, eikä reunakasvuston kompensaatiota voikaan yleistää niihin. Vaikka aukoista ei näyttänyt olevan juuri haittaa satotasolle ensimmäistä aukotusta seurannutta satoa lukuun ottamatta, aukkojen selkeä haittapuoli oli rikkakasvien määrän lisääntyminen. Täydennyskylvön yksi etu onkin rikkakasvipaineen vähentäminen.

Täydennyskylvöön ja sen onnistumiseen liittyy monia eri tekijöitä. Tässä kokeessa täydennyskylvö tehtiin keväällä heti, kun pelto kantoi traktoria. Keväiden välillä oli eroja täydennyskylvön onnistumisessa, ja se onnistui parhaiten keväällä 2016 kokeella 2. Kevätkosteuden hyödyntäminen on erittäin tärkeää täydennyskylvön onnistumisen kannalta. Tähän päätyivät myös Hakkola (1995) ja Kurki \& Valo (2013). Keskikesällä täydennyskylvö on haastavinta, sillä kuivuus ja kilpailu olemassa olevan kasvuston kanssa vaikeuttavat orastumista, mutta myöhemmin elo-syyskuussa onnistumistodennäköisyys on suurempi (Kurki \& Valo 2013). Orastumishavaintojen perusteella täydennyskylvöt onnistuivat hyvin, mutta vuonna 2015 kokeessa 1 satovastetta täydennyskylvölle ei kuitenkaan saatu seuraavanakaan vuonna. Tämä saattaa johtua liian myöhäisestä täydennyskylvöstä vuonna 2015 ja siten heikommasta kilpailuasemasta nopeimman kevätkasvun aikaan. Huguenin-Elie ym. (2006) arvioivat kosteusolosuhteiden ja täydennyskylvettävän nurmen lajiston kilpailukyvyn olevan keskeisimpiä tekijöitä täydennyskylvön onnistumisen kannalta.

Täydennyskylvön vaikutus näkyi selvästi vasta kylvöä seuraavana vuonna, joten täydennyskylvö on syytä tehdä riittävän varhaisessa vaiheessa. Vasta itäneet versot on lisäksi syytä huomioida mm. kasvinsuojeluruiskutuksia ajoitettaessa taimivaurioiden välttämiseksi. Syysitoiset rikkakasvit kannattaakin torjua jo edeltävänä syksynä. Vantaiden käyttö aiheutti toisinaan pientä sadon alenemaa ensimmäisessä sadossa, mutta käytännön kannalta alenema oli merkityksetön. Kokeessa 2 havaittiin, että vaikka täydennyskylvö lisäsi selvästi nurmen tiheyttä kaikilla kolmella aukotetulla koejäsenellä, sadon määrä nousi käytännön kannalta merkittävästi vain kaikkein korkeimmalla aukkoisuustasolla, jonka tiheys lähtötilanteessa oli vain 30\%. Käytännössä näin aukkoista nurmea tuskin enää 
täydennyskylvettäisiin, vaan se perustettaisiin kokonaan uudelleen. Tiheyden lisääntymisen heikko vaikutus sadon määrään on ymmärrettävä aukkoisuustasojen vertailun pohjalta. Mikäli peltomittakaavassa aukot ovat suurempia, eikä aukkojen reunojen kompensaatio toimi yhtä voimakkaasti, voi täydennyskylvöllä olla merkittävämpi vaikutus satoon.

Tässä kokeessa täydennyskylvö tehtiin nurmiheinillä. Apiloiden täydennyskylvön tiedetään onnistuvan helpommin kuin heinien (Hakkola 1995, Kurki \& Valo 2013). Mm. Niemeläinen ym. (2014) havaitsivat selvän sadonlisän kahtena täydennyskylvöä seuraavana vuonna, kun viisi vuotta vanha heinänurmi täydennyskylvettiin puna-apilalla toukokuussa, kasvustoa ei lannoitettu ja se korjattiin vain kerran heinäkuun puolivälissä. Toisaalta myös apilalla on saatu tuloksia, joissa täydennyskylvön silmämääräisestä onnistumisesta huolimatta vaikutus sadon määrään oli vähäinen eikä sadon määrä eronnut täydennyskylvämättömästä koejäsenestä (Lötjönen 2014).

\section{Johtopäätökset}

Kokeiden aikana saatiin kokemuksia sekä epäonnistuneesta että onnistuneesta täydennyskylvöstä. Onnistuessaan täydennyskylvö lisäsi selvästi nurmen tiheyttä ja vähensi rikkakasvipainetta, mutta vaikutus sadon määrään oli vähäinen ja käytännön kannalta merkityksetön lukuun ottamatta erittäin aukkoista koejäsentä. Vaikutukset sulavuuteen olivat vieläkin vähäisempiä. Tämän tutkimuksen perusteella heinäkasveilla toteutettavan täydennyskylvön satohyöty on hyvin epävarma kokeiden kaltaisella kasvuston aukkoisuudella. Täydennyskylvö nosti kokonaissatoa vain yhtenä vuonna, kun nurmen tiheys oli noin 30\%. Tällöinkin satohyöty toteutui vasta täydennyskylvöä seuraavana vuonna. Tutkimuksessa havaittiin, että aukkojen ollessa pieniä (halkaisija alle $40 \mathrm{~cm}$ ) nurmi pystyi kompensoimaan alentunutta tiheyttä tehokkaasti aukkojen laitojen rotevammalla kasvustolla. Vaikka tämän tutkimuksen perusteella täydennyskylvöä heinäseoksella ei voida suositella satotason nostamiseen, tilatasolla täydennyskylvö voi olla kannattava toimenpide nurmien moninaisen aukkorakenteen vuoksi. Täydennyskylvöä olisi tärkeää tutkia lohkomittakaavassa ja muilla nurmilajeilla, kuten puna-apilalla tai yksivuotisilla nurmikasveilla (mm. italianraiheinä).

\section{Kiitokset}

Kokeet toteutettiin Pohjois-Savon alueella 2015-2018 toimivassa Nurmet Rahaksi -hankkeessa, jota rahoittaa Euroopan maaseudun kehittämisen maatalousrahasto Pohjois-Savon ELY-keskuksen kautta.

\section{Kirjallisuus}

Hakkola, H. 1995. Nurmen täydennyskylvö onnistuu parhaiten keväällä. Koetoiminta ja käytäntö 16.12.1995. Maatalouden tutkimuskeskus. s. 54-55.

Huguenin-Elie, O., Stutz, C., Gago, R., Kessler, W. \& Lüscher, A. 2006. Influence of the seeder type and the initial sward composition on the success of overseeding. Teoksessa: Lloveras. J. ym. (toim.). Sustainable Grassland Productivity. Proceedings of the $21^{\text {st }}$ General Meeting of the European Grassland Federation. Badajoz, Spain 3-6 April 2006. s. 137-139.

Kurki, P. 2010. Täydennyskylvö. Teoksessa: Peltonen, S. ym. (toim.). Nurmirehujen tuotanto ja käyttö. Tieto Tuottamaan 132. ProAgria Keskusten Liitto. s. 46-48.

Kurki, P. \& Valo, R. 2013. Nurmen täydentäminen osaksi nurmenhoitoa. Pellot tuottamaan -hanke. https://www.proagria.fi/sites/default/files/attachment/netti2013_taydennyskylvo_logot.pdf

Lötjönen, T. 2014. Nurmien sadontuottokyvyn ylläpitäminen täydennyskylvöllä. Teoksessa: Huuskonen, A. (toim.). Edistystä luomutuotantoon -loppuraportti. MTT Raportti 175: 22-27.

Niemeläinen, O., Hyvönen, T., Jauhiainen, L., Lötjönen, T., Virkkunen, E. \& Uusi-Kämppä, J. 2014. Hoidettu viljelemätön pelto biokaasuksi: biomassan sopivuus syötteeksi ja korjuun vaikutukset tukiohjelmien muiden tavoitteiden saavuttamiseen. HVP-biokaasuksi-hankkeen loppuraportti. MAKERA: Dnro 2619/312/2009. 31 s. http://urn.fi/URN:NBN:fi-fe2014030415897

Virkajärvi, P., Rinne, M., Mononen, J., Niskanen, O., Järvenranta, K. \& Sairanen, A. 2015. Dairy production systems in Finland. Teoksessa: A. van den Pol-van Dasselaar ym. (toim.). Grassland and forages in high output dairy farming systems: Proceedings of the 18th symposium of the European Grassland Federation, Wageningen, the Netherlands, 15-17 June 2015. Grassland Science in Europe 20: 51-66. 